\title{
Other Site of New Distant Metastasis Tumor Event
}

National Cancer Institute

\section{Source}

National Cancer Institute. Other Site of New Distant Metastasis Tumor Event. NCI

Thesaurus. Code C159567.

A directive to specify the other site of the new distant metastatic tumor event. 